\title{
Research on the Value Orientation of Employment in Colleges and Universities under the Age of Big Data
}

\author{
Renyuan Dou, Gaowei Dong \\ School of Marxism, China Pharmaceutical University, Nanjing, China \\ Email: cpudry@163.com
}

How to cite this paper: Dou, R.Y. and Dong, G.W. (2019) Research on the Value Orientation of Employment in Colleges and Universities under the Age of Big Data. Open Journal of Social Sciences, 7, 49-57. https://doi.org/10.4236/jss.2019.78004

Received: July 5, 2019

Accepted: August 6, 2019

Published: August 9, 2019

Copyright (อ 2019 by author(s) and Scientific Research Publishing Inc. This work is licensed under the Creative Commons Attribution International License (CC BY 4.0).

http://creativecommons.org/licenses/by/4.0/

\section{(c) (i) Open Access}

\begin{abstract}
The research object of this paper is the graduates of Jiangsu Province in 2019. It mainly explores their professional values in the era of big data, and relates to the influence of personal subjective will and professional values on employment choices. Starting from the background and significance of the introduction, this paper understands the influencing factors and roles of professional values and the influence of employment choices. By designing questionnaires and issuing questionnaires, collecting data and analyzing the correlation, we can find out how college students "personal characteristics and professional values affect their employment choices, and the relationship between professional values and employment choices. In order to provide some suggestions for college students' career planning, college students" career choice education and the criteria for enterprises to recruit new graduates.
\end{abstract}

\section{Keywords}

Big Data, College Employment, Value Orientation

\section{Introduction}

With the deepening of marketization, as a kind of talent resources, college students are increasingly pushed to the market, and self-employment is greatly strengthened [1]. Especially since the 21st century, with the development of the trend of economic globalization, the value orientation of College Students' employment has changed dramatically in the competition between selection and selection, presenting the characteristics of multi-objective, changeable, discontinuous and hierarchical unstructured data. However, the advantages of large 
data analysis methods, such as large capacity, diversity and high growth rate, are in good agreement with the requirements of analyzing the value orientation of college students' employment [2] [3].

In today's information age, through collecting, processing and analyzing all or almost all of the data, we can observe and study the characteristics and trends of College Students' employment value orientation from a macro perspective, in order to tap the potential relationship between them and the employment of College students better, so as to take timely measures to make the original abstract and complex data better serve the employment of College students and provide meaningful guidance for employment and entrepreneurship education in Colleges and universities, and properly solve the problem of brain drain and imbalance of regional development.

\section{Implementation and Results of Questionnaire Design}

\subsection{Preliminary Design and Pre-Distribution of Questionnaires}

The questionnaire is mainly designed for senior graduates in Jiangsu. The dimension of vocational values has an impact on employment choice. Questionnaire is divided into two aspects, the first is basic information, and the second is the importance of choosing the degree of conformity of occupational values dimension.

\subsection{Formal Issuance and Recovery of Questionnaires}

After the completion of the questionnaire design, the formal issuance will be through the point-to-point return visit to distribute and recycle information in different time periods. This survey adopts the method of questionnaire survey. The questionnaire was sent out and recycled by the Weixin group leaders of the graduating class of Sanya University in 2019. 250 questionnaires were sent out and 233 questionnaires were collected, of which 200 were valid.

\subsection{Sample Data Selection and Correlation Analysis}

Based on the purpose of the research design, the statistical methods used in this study are: descriptive statistical analysis, Pearson correlation analysis (bivariate, partial correlation), comparative mean, regression analysis and so on.

1) Pearson correlation data analysis

According to the bivariate correlation analysis in Table 1, the correlation between "work closely related to my major" and "your age" is -0.157 , because $\mathrm{P}=$ $0.026<0.05$, and shows a significant level of 0.05 . Therefore, there is a significant positive correlation between "work is closely related to my major" and "your age". The correlation between "school can provide career guidance courses" and "can improve their intelligence or technical level" is 0.333 , because $\mathrm{P}=0.000<0.01$, and shows a significant level of 0.01 , which shows that "work is closely related to my major" and "your age" have a significant positive correlation. Different age groups have a certain understanding of the major they are 
Table 1. Bivariate correlation analysis.

\begin{tabular}{|c|c|c|c|c|c|c|c|}
\hline & & Age & Major & $\begin{array}{l}\text { Organization } \\
\text { type }\end{array}$ & $\begin{array}{c}\text { Enhancing } \\
\text { intelligence or skill }\end{array}$ & $\begin{array}{l}\text { Work is closely } \\
\text { related to my major }\end{array}$ & $\begin{array}{c}\text { Schools can offer } \\
\text { career guidance courses }\end{array}$ \\
\hline \multirow{3}{*}{ Age } & $\begin{array}{c}\text { Pearson } \\
\text { correlation }\end{array}$ & 1 & 0.021 & 0.047 & 0.000 & $-0.157^{\star}$ & -0.054 \\
\hline & $\begin{array}{l}\text { Significance } \\
\text { (bilateral) }\end{array}$ & & 0.770 & 0.510 & 0.996 & 0.026 & 0.449 \\
\hline & $\mathrm{N}$ & 200 & 200 & 200 & 200 & 200 & 200 \\
\hline \multirow{3}{*}{ Major } & $\begin{array}{l}\text { Pearson } \\
\text { correlation }\end{array}$ & 0.021 & 1 & 0.092 & -0.087 & -0.062 & -0.071 \\
\hline & $\begin{array}{l}\text { Significance } \\
\text { (bilateral) }\end{array}$ & 0.770 & & 0.193 & 0.219 & 0.381 & 0.320 \\
\hline & $\mathrm{N}$ & 200 & 200 & 200 & 200 & 200 & 200 \\
\hline \multirow{3}{*}{$\begin{array}{c}\text { Organization } \\
\text { type }\end{array}$} & $\begin{array}{l}\text { Pearson } \\
\text { correlation }\end{array}$ & 0.047 & 0.092 & 1 & 0.099 & -0.069 & 0.025 \\
\hline & $\begin{array}{l}\text { Significance } \\
\text { (bilateral) }\end{array}$ & 0.510 & 0.193 & & 0.165 & 0.334 & 0.723 \\
\hline & $\mathrm{N}$ & 200 & 200 & 200 & 200 & 200 & 200 \\
\hline \multirow{3}{*}{$\begin{array}{l}\text { Enhancing } \\
\text { intelligence } \\
\text { or skill }\end{array}$} & $\begin{array}{l}\text { Pearson } \\
\text { correlation }\end{array}$ & 0.000 & -0.087 & 0.099 & 1 & 0.012 & $0.333^{* *}$ \\
\hline & $\begin{array}{l}\text { Significance } \\
\text { (bilateral) }\end{array}$ & 0.996 & 0.219 & 0.165 & & 0.869 & 0.000 \\
\hline & $\mathrm{N}$ & 200 & 200 & 200 & 200 & 200 & 200 \\
\hline \multirow{3}{*}{$\begin{array}{l}\text { Work is closely } \\
\text { related to } \\
\text { my major }\end{array}$} & $\begin{array}{c}\text { Pearson } \\
\text { correlation }\end{array}$ & $-0.157^{\star}$ & -0.062 & -0.069 & 0.012 & 1 & 0.097 \\
\hline & $\begin{array}{l}\text { Significance } \\
\text { (bilateral) }\end{array}$ & 0.026 & 0.381 & 0.334 & 0.869 & & 0.170 \\
\hline & $\mathrm{N}$ & 200 & 200 & 200 & 200 & 200 & 200 \\
\hline \multirow{3}{*}{$\begin{array}{c}\text { Schools can } \\
\text { offer career } \\
\text { guidance courses }\end{array}$} & $\begin{array}{l}\text { Pearson } \\
\text { correlation }\end{array}$ & -0.054 & -0.071 & 0.025 & $0.333^{* *}$ & 0.097 & 1 \\
\hline & $\begin{array}{l}\text { Significance } \\
\text { (bilateral) }\end{array}$ & 0.449 & 0.320 & 0.723 & 0.000 & 0.170 & \\
\hline & $\mathrm{N}$ & 200 & 200 & 200 & 200 & 200 & 200 \\
\hline
\end{tabular}

*. Significant correlation at 0.05 levels (bilateral). ${ }^{* *}$. Significant correlation at 0.01 levels (bilateral).

studying. Some like the work of their counterparts, but sometimes they have no choice. Sometimes the counterparts who are not interested in the work suddenly quit. In other words, it is not like when choosing a major in the first place that causes problems in choosing the direction of employment and differences in professional values.

According to the bivariate correlation analysis in Table 2, the correlation value between "salary and welfare" and "age" is -0.190 , and shows a significant level of 0.01 , which indicates that there is a significant positive correlation between them. The correlation value between "job stability and employment stability" 
Table 2. Bivariate correlation analysis.

\begin{tabular}{|c|c|c|c|c|c|c|c|c|c|c|c|c|}
\hline & & $\stackrel{8}{4}$ & 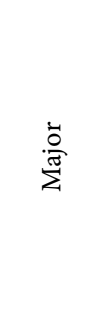 & 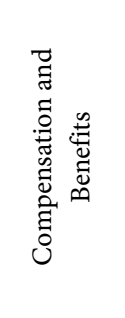 & 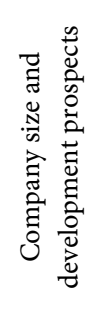 & 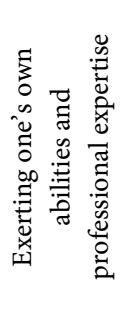 & $\begin{array}{l}\widetilde{J} \\
\ddot{3} \\
\dddot{y} \\
\vdots \\
3\end{array}$ & 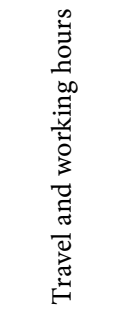 & 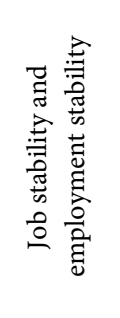 & 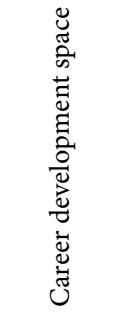 & 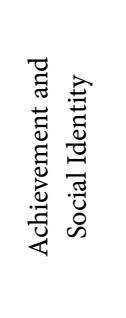 & 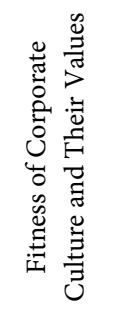 \\
\hline \multirow{3}{*}{ Age } & $\begin{array}{l}\text { Pearson } \\
\text { correlation }\end{array}$ & 1 & 0.021 & $-0.190^{\star *}$ & 0.071 & -0.036 & -0.008 & 0.092 & -0.007 & 0.055 & 0.112 & 0.003 \\
\hline & $\begin{array}{l}\text { Significance } \\
\text { (bilateral) }\end{array}$ & & 0.770 & 0.007 & 0.318 & 0.610 & 0.906 & 0.194 & 0.917 & 0.442 & 0.116 & 0.965 \\
\hline & $\mathrm{N}$ & 200 & 200 & 200 & 200 & 200 & 200 & 200 & 200 & 200 & 200 & 200 \\
\hline \multirow{3}{*}{ Major } & $\begin{array}{l}\text { Pearson } \\
\text { correlation }\end{array}$ & 0.021 & 1 & -0.018 & -0.082 & -0.050 & 0.070 & -0.063 & $0.157^{\star}$ & -0.045 & 0.051 & 0.044 \\
\hline & $\begin{array}{l}\text { Significance } \\
\text { (bilateral) }\end{array}$ & 0.770 & & 0.800 & 0.247 & 0.483 & 0.323 & 0.373 & 0.026 & 0.531 & 0.473 & 0.539 \\
\hline & $\mathrm{N}$ & 200 & 200 & 200 & 200 & 200 & 200 & 200 & 200 & 200 & 200 & 200 \\
\hline \multirow{3}{*}{$\begin{array}{l}\text { Compensation } \\
\text { and Benefits }\end{array}$} & $\begin{array}{l}\text { Pearson } \\
\text { correlation }\end{array}$ & $-0.190^{\star *}$ & -0.018 & 1 & -0.047 & 0.093 & -0.107 & $-0.235^{\star *}$ & $-0.202^{* *}$ & $-0.241^{\star *}$ & $-0.332^{\star *}$ & -0.059 \\
\hline & $\begin{array}{c}\text { Significance } \\
\text { (bilateral) }\end{array}$ & 0.007 & 0.800 & & 0.512 & 0.191 & 0.133 & 0.001 & 0.004 & 0.001 & 0.000 & 0.404 \\
\hline & $\mathrm{N}$ & 200 & 200 & 200 & 200 & 200 & 200 & 200 & 200 & 200 & 200 & 200 \\
\hline \multirow{3}{*}{$\begin{array}{l}\text { Company } \\
\text { size and } \\
\text { development } \\
\text { prospects }\end{array}$} & $\begin{array}{l}\text { Pearson } \\
\text { correlation }\end{array}$ & 0.071 & -0.082 & -0.047 & 1 & -0.108 & -0.097 & -0.008 & $-0.194^{\star *}$ & -0.044 & $-0.366^{\star *}$ & $-0.190^{\star *}$ \\
\hline & $\begin{array}{l}\text { Significance } \\
\text { (bilateral) }\end{array}$ & 0.318 & 0.247 & 0.512 & & 0.127 & 0.170 & 0.911 & 0.006 & 0.536 & 0.000 & 0.007 \\
\hline & $\mathrm{N}$ & 200 & 200 & 200 & 200 & 200 & 200 & 200 & 200 & 200 & 200 & 200 \\
\hline \multirow{3}{*}{$\begin{array}{l}\text { Exerting one's } \\
\text { own abilities } \\
\text { and } \\
\text { professional } \\
\text { expertise }\end{array}$} & $\begin{array}{c}\text { Pearson } \\
\text { correlation }\end{array}$ & -0.036 & -0.050 & 0.093 & -0.108 & 1 & $-0.292^{\star *}$ & -0.107 & -0.090 & $-0.235^{\star *}$ & -0.094 & $-0.201^{\star *}$ \\
\hline & $\begin{array}{l}\text { Significance } \\
\text { (bilateral) }\end{array}$ & 0.610 & 0.483 & 0.191 & 0.127 & & 0.000 & 0.133 & 0.207 & 0.001 & 0.185 & 0.004 \\
\hline & $\mathrm{N}$ & 200 & 200 & 200 & 200 & 200 & 200 & 200 & 200 & 200 & 200 & 200 \\
\hline \multirow{3}{*}{ Work area } & $\begin{array}{l}\text { Pearson } \\
\text { correlation }\end{array}$ & -0.008 & 0.070 & -0.107 & -0.097 & $-0.292^{\star *}$ & 1 & $-0.190^{* *}$ & 0.005 & $-0.193^{\star *}$ & 0.008 & $-0.171^{\star}$ \\
\hline & $\begin{array}{l}\text { Significance } \\
\text { (bilateral) }\end{array}$ & 0.906 & 0.323 & 0.133 & 0.170 & 0.000 & & 0.007 & 0.939 & 0.006 & 0.906 & 0.015 \\
\hline & $\mathrm{N}$ & 200 & 200 & 200 & 200 & 200 & 200 & 200 & 200 & 200 & 200 & 200 \\
\hline \multirow{3}{*}{$\begin{array}{l}\text { Travel and } \\
\text { working } \\
\text { hours }\end{array}$} & $\begin{array}{l}\text { Pearson } \\
\text { correlation }\end{array}$ & 0.092 & -0.063 & $-0.235^{\star *}$ & -0.008 & -0.107 & $-0.190^{* *}$ & 1 & $-0.286^{* *}$ & 0.022 & -0.135 & -0.044 \\
\hline & $\begin{array}{c}\text { Significance } \\
\text { (bilateral) }\end{array}$ & 0.194 & 0.373 & 0.001 & 0.911 & 0.133 & 0.007 & & 0.000 & 0.759 & 0.056 & 0.535 \\
\hline & $\mathrm{N}$ & 200 & 200 & 200 & 200 & 200 & 200 & 200 & 200 & 200 & 200 & 200 \\
\hline
\end{tabular}




\begin{tabular}{|c|c|c|c|c|c|c|c|c|c|c|c|c|}
\hline \multicolumn{13}{|c|}{ Continued } \\
\hline \multirow{3}{*}{$\begin{array}{l}\text { Job stability } \\
\text { and } \\
\text { employment } \\
\text { stability }\end{array}$} & $\begin{array}{l}\text { Pearson } \\
\text { correlation }\end{array}$ & -0.007 & $0.157^{\star}$ & $-0.202^{\star *}$ & $-0.194^{* *}$ & -0.090 & 0.005 & $-0.286^{\star *}$ & 1 & $-0.203^{\star *}$ & 0.093 & -0.034 \\
\hline & $\begin{array}{c}\text { Significance } \\
\text { (bilateral) }\end{array}$ & 0.917 & 0.026 & 0.004 & 0.006 & 0.207 & 0.939 & 0.000 & & 0.004 & 0.192 & 0.634 \\
\hline & $\mathrm{N}$ & 200 & 200 & 200 & 200 & 200 & 200 & 200 & 200 & 200 & 200 & 200 \\
\hline \multirow{3}{*}{$\begin{array}{c}\text { Career } \\
\text { development } \\
\text { space }\end{array}$} & $\begin{array}{l}\text { Pearson } \\
\text { correlation }\end{array}$ & 0.055 & -0.045 & $-0.241^{\star \star}$ & -0.044 & $-0.235^{\star \star}$ & $-0.193^{\star *}$ & 0.022 & $-0.203^{\star *}$ & 1 & -0.073 & -0.041 \\
\hline & $\begin{array}{c}\text { Significance } \\
\text { (bilateral) }\end{array}$ & 0.442 & 0.531 & 0.001 & 0.536 & 0.001 & 0.006 & 0.759 & 0.004 & & 0.307 & 0.560 \\
\hline & $\mathrm{N}$ & 200 & 200 & 200 & 200 & 200 & 200 & 200 & 200 & 200 & 200 & 200 \\
\hline \multirow{3}{*}{$\begin{array}{c}\text { Achievement } \\
\text { and Social } \\
\text { Identity }\end{array}$} & $\begin{array}{l}\text { Pearson } \\
\text { correlation }\end{array}$ & 0.112 & 0.051 & $-0.332^{\star \star}$ & $-0.366^{\star *}$ & -0.094 & 0.008 & -0.135 & 0.093 & -0.073 & 1 & $0.144^{\star}$ \\
\hline & $\begin{array}{c}\text { Significance } \\
\text { (bilateral) }\end{array}$ & 0.116 & 0.473 & 0.000 & 0.000 & 0.185 & 0.906 & 0.056 & 0.192 & 0.307 & & 0.042 \\
\hline & $\mathrm{N}$ & 200 & 200 & 200 & 200 & 200 & 200 & 200 & 200 & 200 & 200 & 200 \\
\hline \multirow{3}{*}{$\begin{array}{c}\text { Fitness of } \\
\text { Corporate } \\
\text { Culture and } \\
\text { Their Values }\end{array}$} & $\begin{array}{c}\text { Pearson } \\
\text { correlation }\end{array}$ & 0.003 & 0.044 & -0.059 & $-0.190^{* *}$ & $-0.201^{\star *}$ & $-0.171^{*}$ & -0.044 & -0.034 & -0.041 & $0.144^{\star}$ & 1 \\
\hline & $\begin{array}{l}\text { Significance } \\
\text { (bilateral) }\end{array}$ & 0.965 & 0.539 & 0.404 & 0.007 & 0.004 & 0.015 & 0.535 & 0.634 & 0.560 & 0.042 & \\
\hline & $\mathrm{N}$ & 200 & 200 & 200 & 200 & 200 & 200 & 200 & 200 & 200 & 200 & 200 \\
\hline
\end{tabular}

**. Significant correlation at .01 levels (bilateral). ${ }^{*}$. Significant correlation at 0.05 levels (bilateral).

and "specialty" is 0.157 , and shows a significant level of 0.05 , which indicates that there is a significant positive correlation between them. The correlation between "travel and working hours" and "salary and benefits" is -0.235 , and shows a significant level of 0.01 , which indicates that there is a significant positive correlation between them. The correlation between "achievement and social identity" and "salary and welfare" is -0.332 , and shows a significant level of 0.01 , which indicates that there is a significant positive correlation between them.

The correlation between "job stability and employment stability" and "company size and development prospects" is -0.194 , and shows a significant level of 0.01 , which indicates that there is a significant positive correlation between them. The correlation between "work area" and "travel and working time" is -0.190 , and shows a significant level of 0.01 , which indicates that there is a significant positive correlation between them. The correlation between "your major is" and "job stability and employment stability" is 0.157 , and shows a significant level of 0.05 , which shows that there is a significant positive correlation between them. The value of the relationship between "giving full play to one's own abilities and professional expertise" and "career development space" is -0.235 , showing a significant level of 0.01 , which indicates that there is a significant positive correlation between them. The value of the relationship between "fit degree of corporate culture and its own values" and "achievement and social identity" is 0.144 , showing a significant level of 0.05 , which shows that there is a significant 
positive correlation between them [3]. The value of the relationship between "fit degree of corporate culture and its own values" and "working area" is -0.171 , and shows a significant level of 0.05 , which shows that there is a significant positive correlation between them.

According to the bivariate correlation analysis in Table 3, the correlation value between the "target" and "type of industry" is 0.149 , and shows a significant level of 0.05 , which indicates that there is a significant positive correlation between them. The correlation value between "can improve intelligence or technology level" and "industry type" is -0.158 , and shows a significant level of 0.05 , which indicates that there is a significant positive correlation between them. The correlation between "job can have a large promotion space" and "industry type" is -0.189 , and shows a significant level of 0.01 , which shows that there is a significant positive correlation between them.

The correlation between "being an authority and being valued by others" and "city level" is -0.213 , and shows a significant level of 0.01 , which indicates that there is a significant positive correlation between them. The correlation between "school can provide career guidance courses" and "city level" is -0.185 , and shows a significant level of 0.01 , which shows that there is a significant positive correlation between them. The correlation value between "industry type" and "target affecting job selection" is 0.149 , and shows a significant level of 0.05 , which indicates that there is a significant positive correlation between them.

The correlation between "city level" and "being the authority of work and valued by others" is -0.213 , and shows a significant level of 0.01 , which indicates that there is a significant positive correlation between them. The correlation between "economic income" and "being the authority of work and valued by others" is 0.200 , and shows a significant level of 0.01 , which indicates that there is a significant positive correlation between them. The correlation value between "becoming the authority of work and being valued by others" and "economic income" is 0.200 , and shows a significant level of 0.01 , which indicates that there is a significant positive correlation between them. The correlation between "job can have a large promotion space" and "economic income" is 0.229 , and shows a significant level of 0.01 , which shows that there is a significant positive correlation between them.

The correlation value between "industry type" and "can improve intelligence or technology level" is -0.158 , and shows a significant level of 0.05 , which indicates that there is a significant positive correlation between them. The correlation value between "can improve intelligence or technical level" and "school can provide employment guidance curriculum" is 0.333 , and shows a significant level of 0.01 , which shows that there is a significant positive correlation between them. The correlation value between "job can have a large promotion space" and "school can provide employment guidance courses" is 0.266 , and shows a significant level of 0.01 , which shows that there is a significant positive correlation between them. 
Table 3. Bivariate correlation analysis.

\begin{tabular}{|c|c|c|c|c|c|c|c|c|c|}
\hline & & 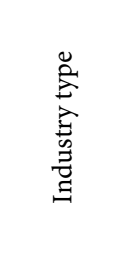 & 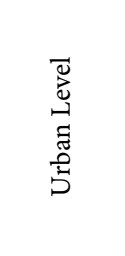 & 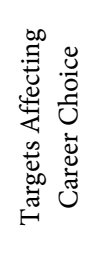 & 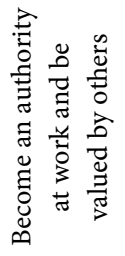 & 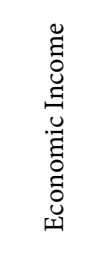 & 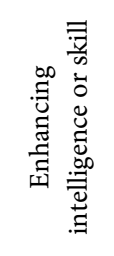 & 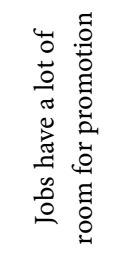 & 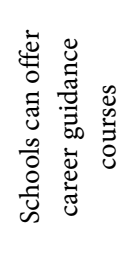 \\
\hline \multirow{3}{*}{ Industry type } & $\begin{array}{c}\text { Pearson } \\
\text { correlation }\end{array}$ & 1 & 0.001 & $0.149^{*}$ & 0.048 & -0.061 & $-0.158^{*}$ & $-0.189^{\star *}$ & -0.103 \\
\hline & $\begin{array}{l}\text { Significance } \\
\text { (bilateral) }\end{array}$ & & 0.990 & 0.035 & 0.504 & 0.388 & 0.025 & 0.007 & 0.145 \\
\hline & $\mathrm{N}$ & 200 & 200 & 200 & 200 & 200 & 200 & 200 & 200 \\
\hline \multirow{3}{*}{ Urban Level } & $\begin{array}{l}\text { Pearson } \\
\text { correlation }\end{array}$ & 0.001 & 1 & 0.099 & $-0.213^{* *}$ & -0.115 & -0.043 & -0.110 & $-0.185^{\star \star}$ \\
\hline & $\begin{array}{l}\text { Significance } \\
\text { (bilateral) }\end{array}$ & 0.990 & & 0.163 & 0.002 & 0.104 & 0.543 & 0.121 & 0.009 \\
\hline & $\mathrm{N}$ & 200 & 200 & 200 & 200 & 200 & 200 & 200 & 200 \\
\hline \multirow{3}{*}{$\begin{array}{c}\text { Targets } \\
\text { Affecting } \\
\text { Career Choice }\end{array}$} & $\begin{array}{l}\text { Pearson } \\
\text { correlation }\end{array}$ & $0.149^{*}$ & 0.099 & 1 & -0.077 & 0.016 & 0.041 & -0.033 & 0.021 \\
\hline & $\begin{array}{l}\text { Significance } \\
\text { (bilateral) }\end{array}$ & 0.035 & 0.163 & & 0.277 & 0.824 & 0.565 & 0.644 & 0.772 \\
\hline & $\mathrm{N}$ & 200 & 200 & 200 & 200 & 200 & 200 & 200 & 200 \\
\hline \multirow{4}{*}{$\begin{array}{c}\text { Become an } \\
\text { authority at } \\
\text { work and } \\
\text { be valued } \\
\text { by others }\end{array}$} & $\begin{array}{l}\text { Pearson } \\
\text { correlation }\end{array}$ & 0.048 & $-0.213^{\star *}$ & -0.077 & 1 & $0.200^{* *}$ & 0.057 & 0.123 & 0.109 \\
\hline & $\begin{array}{l}\text { Significance } \\
\text { (bilateral) }\end{array}$ & 0.504 & 0.002 & 0.277 & & 0.004 & 0.419 & 0.083 & 0.123 \\
\hline & $\mathrm{N}$ & 200 & 200 & 200 & 200 & 200 & 200 & 200 & 200 \\
\hline & $\begin{array}{l}\text { Pearson } \\
\text { correlation }\end{array}$ & -0.061 & -0.115 & 0.016 & $0.200^{\star *}$ & 1 & $0.258^{\star *}$ & $0.229^{\star *}$ & 0.129 \\
\hline \multirow[t]{2}{*}{$\begin{array}{l}\text { Economic } \\
\text { Income }\end{array}$} & $\begin{array}{c}\text { Significance } \\
\text { (bilateral) }\end{array}$ & 0.388 & 0.104 & 0.824 & 0.004 & & 0.000 & 0.001 & 0.068 \\
\hline & $\mathrm{N}$ & 200 & 200 & 200 & 200 & 200 & 200 & 200 & 200 \\
\hline \multirow{3}{*}{$\begin{array}{c}\text { Enhancing } \\
\text { intelligence } \\
\text { or skill }\end{array}$} & $\begin{array}{l}\text { Pearson } \\
\text { correlation }\end{array}$ & $-0.158^{\star}$ & -0.043 & 0.041 & 0.057 & $0.258^{* *}$ & 1 & $0.197^{\star *}$ & $0.333^{* *}$ \\
\hline & $\begin{array}{l}\text { Significance } \\
\text { (bilateral) }\end{array}$ & 0.025 & 0.543 & 0.565 & 0.419 & 0.000 & & 0.005 & 0.000 \\
\hline & $\mathrm{N}$ & 200 & 200 & 200 & 200 & 200 & 200 & 200 & 200 \\
\hline \multirow{3}{*}{$\begin{array}{l}\text { Jobs have } \\
\text { a lot of room } \\
\text { for promotion }\end{array}$} & $\begin{array}{l}\text { Pearson } \\
\text { correlation }\end{array}$ & $-0.189^{\star *}$ & -0.110 & -0.033 & 0.123 & $0.229^{* *}$ & $0.197^{\star *}$ & 1 & $0.266^{* *}$ \\
\hline & $\begin{array}{c}\text { Significance } \\
\text { (bilateral) }\end{array}$ & 0.007 & 0.121 & 0.644 & 0.083 & 0.001 & 0.005 & & 0.000 \\
\hline & $\mathrm{N}$ & 200 & 200 & 200 & 200 & 200 & 200 & 200 & 200 \\
\hline \multirow{3}{*}{$\begin{array}{c}\text { Schools can } \\
\text { offer career } \\
\text { guidance } \\
\text { courses }\end{array}$} & $\begin{array}{l}\text { Pearson } \\
\text { correlation }\end{array}$ & -0.103 & $-0.185^{\star *}$ & 0.021 & 0.109 & 0.129 & $0.333^{\star *}$ & $0.266^{\star *}$ & 1 \\
\hline & $\begin{array}{c}\text { Significance } \\
\text { (bilateral) }\end{array}$ & 0.145 & 0.009 & 0.772 & 0.123 & 0.068 & 0.000 & 0.000 & \\
\hline & $\mathrm{N}$ & 200 & 200 & 200 & 200 & 200 & 200 & 200 & 200 \\
\hline
\end{tabular}

*. Significant correlation at 0.05 levels (bilateral). ${ }^{* *}$. Significant correlation at 0.01 levels (bilateral). 
Based on the above data analysis, it can be seen that the prevalent occupational values of the graduates are "travel and working time, salary and welfare, city type, company size and development prospects, rich economic income, industry type, working area, improving their intelligence or technical level, promotion space and authority can be valued by others". Give full play to own abilities and professional expertise, social identity, corporate culture and their own values, and so on. At the beginning of the formation of these ideas, they directly or indirectly affected students' personal employment choices. Comparatively speaking, objective factors account for a larger proportion than subjective factors, which shows that students pay more attention to material enjoyment, can solve the physiological needs of food and clothing, and only on this basis will they pay attention to spiritual sustenance and self-realization value. The formation of students' willingness to choose employment is based on their personal values of "job form, characteristics, internal and external conditions, living environment, organizational environment background and prospects, industry background, personal quality and ability". Therefore, it shows that vocational values have an impact on College Students' employment choices.

\section{Suggestions on College Students' Employment Choice}

1) In the case of correct personal professional values, it is suggested that when choosing a company for employment, we should carefully confirm whether the recruitment information is false or not, and understand the company's basic situation, corporate culture management system and relevant regulations [4]. Investigate employee satisfaction loyalty, understand promotion channels and development space, clearly sign labor contract terms, and clear training system content and incentive means. Relatively, enterprises should provide real information, satisfy employees' needs as much as possible rationalize management with humanity, improve employees' entertainment facilities, complete training system, popular incentives, and put forward more suggestions on salary system and welfare activities to satisfy and stimulate employees' enthusiasm. Schools should improve the quality of school enrollment, the selection and certification of enterprises' entry and exit, the arrangement of recruitment venues and personnel, and propose setting up students' career planning courses as compulsory courses to enhance students' awareness of employment choices, so as to better go to society, introduce excellent teachers and enhance the level of teaching staff. Life instructors should pay more attention to students' employment goals, adjust their psychological state, actively guide students to the right direction of development, and improve students' employment awareness. Students should be scheduled to attend the school recruitment meeting according to their curriculum time, do a good job of school-enterprise propaganda programs, and avoid conflicts [5]. Schools should hold more expert seminars to effectively learn from foreign high-quality theoretical experience.

2) In the case of incorrect personal professional values, parents should actively pay attention to and guide them. Life instructors and professional teachers 
should always pay attention to students' psychological changes and find positive communication and heart-to-heart talk. In the case of objective conditions, students only use their own judgment to determine right and wrong, or follow the advice of their peers to choose the right job. At the beginning of the formation of individual career planning, more opportunities are needed to strengthen their own shortcomings [6]. It is suggested to strengthen their skills training and psychological endurance to ensure physical and mental health. The government and relevant departments should pay attention to the employment problem, strengthen supervision over whether the operation and management of enterprises are in accordance with the rules and regulations, vigorously encourage graduates to innovate and start businesses and give subsidies, hold more symposiums of government organs and units of schools and enterprises, and solve the problem of low employment rate and rising unemployment rate.

\section{Conclusion}

Generally speaking, during the period of students' value formation, the state and universities should use big data to find out the changing law of College Students' employment value orientation hidden in the image, adopt more refined methods, and intervene in the formation of College Students' values more reasonably and effectively. In the process of education, we should also introduce foreign values education concepts and cultivate them scientifically, systematically and pertinently in an invisible way.

\section{Conflicts of Interest}

The authors declare no conflicts of interest regarding the publication of this paper.

\section{References}

[1] Huang, W. (2017) The Impact of Work Values on College Students' Employment Choices. Qiannan Normal University for Nationalities, 11, 11-15.

[2] Chen, K. (2010) A Study on the Relationship between College Students' Work Values and Career Choice Tendency. Hubei Normal University, No. 2, 17.

[3] Liu, X. and Wu, R. (2011) Characteristics and Countermeasures of Work Values of Post-90s College Students. Department of Psychology, Suzhou University, Suzhou, 23.

[4] Huang, X. (2011) Study on the Influence of Family Environment and Work Values on College Students' Career Choice Efficacy. Nanchang University, Nanchang.

[5] Lu, X. (2014) A Comparative Study of the Work Values of College Students-The Students of Three Universities in Jilin Province as the Research Object. Yanbian University, Yanji.

[6] Han, X. (2015) Higher Vocational Students' Work Values Education Based on Enterprise Demand. Yantai Vocational College, Yantai. 